\title{
ANALISIS HARMONISASI KOMUNIKASI ANTARA NELAYAN JARING BOBO DALAM USAHA PENANGKAPAN IKAN DI KABUPATEN SERAM BAGIAN BARAT (SBB)
}

\author{
Masni Sanmas ${ }^{1}$ \\ Jurusan Ilmu Komunikasi Sekolah Tinggi Ilmu Komunikasi (STIKOM), Muhammadiyah Jayapura \\ Email: sanmasanie@gmail.com
}

\begin{abstract}
ABSTRAK
Nelayan adalah orang yang sehari-hari beraktivitas mencari ikan di laut. Produktivitas hasil tangkap yang dimiliki nelayan sangat ditentukan oleh baik buruknya kondisi alam, misalnya keadaan cuaca yang kurang baik, faktor lain yang sangat berpengaruh terhadap kurangnya produktivitas hasil tangkap juga disebabkan karena faktor internal dari kelompok nelayan itu sendiri. Faktor internal yang dimaksud ialah hubungan sosial di dalam kelompok jaring bobo. Penelitian ini bertujuan untuk menganalisis harmonisasi komunikasi antara nelayan selama proses menangkap ikan di Kabupaten Seram Bagian Barat (SBB), dan mendeskripsikan upaya yang telah dilakukan untuk membangun komunikasi yang harmonis antar nelayan selama berlangsungnya proses penangkapan ikan di Kabupaten Seram Bagian Barat (SBB). Metode dalam penelitian ini adalah metode kualitatif deskriptif. Pengumpulan data diperoleh dengan cara pengamatan dan wawancara langsung terhadap 22 informan, data kemudian dianalisis menggunakan model interaktif Miles dan Huberman. Hasil yang diperoleh dari penelitian ini adalah, nelayan di Kabupaten Seram Bagian Barat dalam menjalankan usaha jaring bobo sering terjadi konflik yng mengakibatkan komunikasi antar nelayan tidak berjalan harmonis, dan ada juga nelayan yang komunikasi mereka berjalan harmonis. Upaya yang di gunakan dalam membangun komunikasi yang harmonis dengan saling menghargai, kejujuran, kerjasama, dan adanya tanggung jawab. Serta Pentingnya harmonisasi dalam kelompok adalah untuk menciptakan adanya rasa nyaman diantara nelayan.
\end{abstract}

Kata Kunci: Komunikasi Kelompok, Harmonisasi Komunikasi, Hasil Tangkapan

\section{HARMONIZATION ANALYSIS OF COMMUNICATION BETWEEN BOBO NETWORK FISHERS IN FISHING BUSINESS IN WEST SERAM DISTRICT (SBB)}

\begin{abstract}
Fishermen is part of fishing units that play an important role in fishing operations at sea. The productivity of fishermen's catches mostly determined by the merits of natural conditions, for example bad weather conditions, other factors that greatly affect the lack of productivity of catches are also caused by internal factors from the group of fishermen themselves. The internal factor is social relations within the bobo nets group. This study aims to analyze the harmonization of communication between fishermen in the fishing business in West Seram District (SBB), and describing the efforts that have been made to build harmonious communication between fishermen during the fishing process in West Seram District (SBB).This research uses descriptive qualitative method. Data were obtained through direct observation and interviews of 22 informants and analyzed using Miles and Huberman interactive model.The results showed that, fishermen in West Seram District in running bobo net business often occur conflicts yng resulting in communication between fishermen not running harmoniously, and there are also fishermen whose communication they run harmoniously. Efforts are in use in building a harmonious communication with mutual respect, honesty, cooperation, and the responsibility. And the importance of harmonization in groups is to create a sense of comfort among the fishermen.
\end{abstract}

Keywords: Group Communication, Communication Harmonization, Catch 
Korespondensi: Masni Sanmas, S.Sos, M.I.Kom. Sekolah Tinggi Ilmu Komunikasi (STIKOM) Muhammadiyah Jayapura. Jl Abepantai No 25, ( 99351) No. Telp/HP : 082187808268 E-mail: sanmasanie@ @ gmail.com

\section{PENDAHULUAN}

Keberhasilan seseorang dalam memenuhi keinginan dan kebutuhan hidupnya, sangat ditentukan oleh kemampuannya dalam melakukan komunikasi dengan individu lain. Kemampuan komunikasi antar individu, sangat ditentukan oleh kualitas pesan yang disampaikan. Kualitas komunikasi, baik proses maupun hasil, merupakan faktor penentu efektif dan tidaknya seseorang dalam melakukan komunikasi dengan orang lain. Komunikasi dapat berlangsung secara efektif, apabila penerima dapat menerima pesan dengan baik dari pengirm. Sebaliknya komunikasi tidak efektif menyebabkan adanya kesenjangan antara penerima dalam menangkap makna suatu pesan dengan apa yang dimaksud oleh pengirim.

Dedy Mulyana dalam Nasrullah (2012: 1) mengatakan komunikasi menjadi suatu hal penting dalam kehidupan manusia. Manusia dikatakan "tersesat" apabila tidak melakukan komunikasi dengan yang lainnya, karena ia tidak dapat beradaptasi dengan lingkungan sosial dimana dia berada. Dalam kehidupan sosial, individu akan saling berinteraksi antar sesama dengan tujuan saling mempengaruhi untuk tujuan tertentu.

Harold D. Lasswell (Cangara. 2014:2) Mengatakan, terdapat tiga fungsi utama yang menjadi dasar manusia berkomunikasi: Pertama adanya keinginan dalam mengontrol lingkungan. Dengan komunikasi, setiap orang akan mengidentifikasi kesempatan-kesempatan yang akan digunakanan dan terhindar dari setiap ancaman. Setiap orang akan dengan mudah mendapatkan informasi terkait suatu peristiwa ketika melakukan komunikasi dengan orang lain, bahkan dengan komunikasi akan menambah wawasan dan pengetahuan berdasarkan informasi yang diperoleh dari lingkungannya. Kedua, yaitu manusia berusaha untuk menyesuaikan diri dengan lingkungan dimana dia berada. Manusia bukan hanya beradaptasi terhadap sesamanya dan alam sekitar namun juga lingkungan masyarakat dimana manusia hidup dalam tantangan yang artinya bahwa manusia harus hidup harmonis dan bersahabat dengan alam di sekitarnya. Ketiga, upaya untuk melakukan transformasi sosialisasi. Untuk mempertahankan keberadaannya, manusia secara terus menerus melakukan pertukaran nilai, perilaku dan peranan di lingkungan dimana dia berada.

Masyarakat Kabupaten Seram Bagian Barat (SBB), merupakan masyarakat pesisir, yang sebagian besar menggantungkan hidupnya pada hasil laut, kebanyakan dari mereka bekerja sebagai nelayan. Nelayan adalah orang yang bekerja mencari dan menangkap ikan di laut. Sebagian besar nelayan di Kabupaten Seram Bagian Barat bekerja pada kelompok nelayan yang dalam melakukan usaha penangkapan ikan, mereka menggunakan alat tangkap pukat cincin, masyarakat Maluku menyebutnya jaring bobo. Nelayan jaring bobo terdiri atas; nelayan juragan, dan masnait (Karyawan).

Produktivitas hasil tangkap yang dimiliki nelayan sangat ditentukan oleh baik buruknya kondisi alam, misalnya keadaan cuaca yang kurang 
baik, faktor lain yang sangat berpengaruh terhadap kurangnya produktivitas hasil tangkap juga disebabkan karena faktor internal dari kelompok nelayan itu sendiri. Faktor internal yang dimaksud ialah hubungan sosial di dalam kelompok jaring bobo.

Berdasarkan informasi awal yang penulis temukan bahwa nelayan di Kabupaten Seram Bagian Barat (SBB) sering terjadi konflik, yang mengakibatkan komunikasi antara mereka tidak harmonis. Hal ini karena, adanya saling curiga antar sesama nelayan, serta kurang baiknya pelayanan yang di lakukan oleh juragan kepada masnait. Akibat dari kurang harmonisnya komunikasi antara nelayan, menyebabkan kerjasama antar mereka pun kurang baik, sehingga berpengaruh pada hasil tangkapan yang diperoleh. Carolina (2015) dalam penelitiannya mengatakan bahwa, baik buruknya kinerja karyawan sangat di tentukan oleh kemampuan berkomunikasi dan bekerjasama dalam kelompok

Penelitian ini bertujuan untuk: (1). Menganalisis harmonisasi komunikasi antara nelayan dalam upaya menangkap ikan di Kabupaten Seram Bagian Barat (SBB). Dan (2). Mendeskripsikan upaya yang telah dilakukan untuk membangun komunikasi yang harmonis antar nelayan selama berlangsungnya proses penangkapan ikan di Kabupaten Seram Bagian Barat (SBB

\section{Komunikasi}

Komunikasi sangat berperan penting dalam kehidupan manusia. Secara kodrat manusia akan melakukan komunikasi secara terus meneruk dengan orang lain dan menjadi konsekuensi dalam suatu hubungan social.

Komunikasi dari segi etimologi berasal dari bahasa latin yaitu communicatio, dari kata communis artinya sama, kata sama mengandung makna, sama tentang suatu hal. Jadi komunikasi dikatakan efektif apabila antar pengirim dan penerima memiliki pengertian yang sama atas pesan yang disampaikan. Atau dengan kata lain, komunikasi akan terus berlanjut ketika penerima memahami pesan yang disampaikan pengirim. Begitupun sebaliknya, akan terjadi miss komunikasi jika penerima tidak mengerti pesan yang disampaikan oleh pengirim.

Menurut Istilah, Komunikasi berarti suatu proses mengirim ide atau pesan dari individu yang satu ke individu lainnya. Pengertian ini menunjukan bahwa, proses komunikasi melibatkan beberapa orang dimana seorang/kelompok bertindak sebagai pengirim dan lainnya sebagai penerima. Onong (2008: 3)

Menurut Dedy Mulyana (Rohim. 2009: 9) komunikasi berarti proses dimana suatu pesan dikirim oleh pengirim kepada penerima dengan tujuan mengubah perilaku seseorang. Tubs dan Moss, (Mulyana. 2010: 69) Komunikasi adalah proses membentuk sebuah makna diantara orangorang yang terlibat dalam komunikasi. Jadi, dapat disimpulkan komunikasi itu terjadi karena ada hubungan antar dua orang atau lebih secara interaktif menyampaikan pesan, pendapat, atau informasi baik secara verbal maupun non verbal, sehingga membentuk suatu pengertian yang sama.

Komunikasi dikatakan efektif apabila terdapat unsur-unsur dalam proses komunikasi itu sendiri. 
Komunikasi adalah proses dimana seorang mengirim pesan kepada orang lain yang bertujuan untuk mengubah perilaku orang tersebut. Jadi secara singkat dapat disimpulkan bahwa

Komunikasi tidak akan terjadi tanpa unsurunsur yang mendukung proses komunikasi itu sendiri.

Miller dan Cherry, (Cangara. 2014: 26-30) mengemukakan unsur komunikasi yang dapat digambarkan berikut ini:

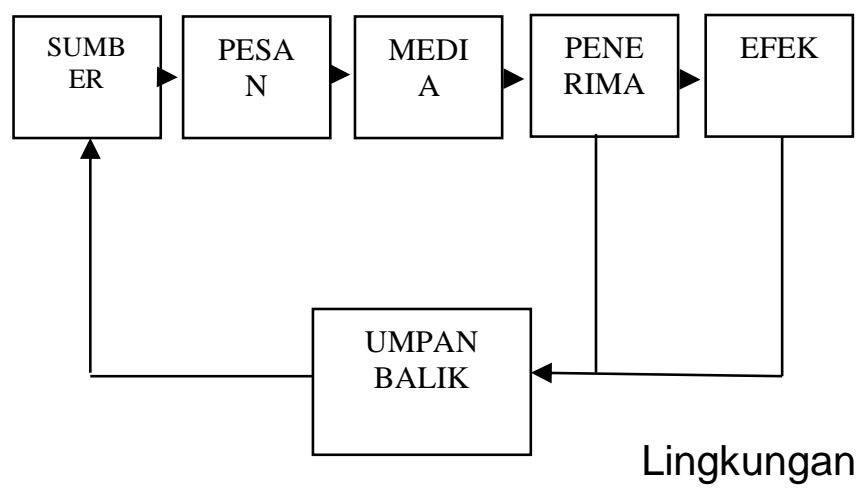

Gambar 2.1 Unsur proses Komunikasi

Berikut merupakan penjelasan terkait unsur komunikasi yang dikemukakan oleh Miller dan Cherry dapat dijelaskan sebagai berikut:

1. Sumber

Semua peristiwa komunikasi akan melibatkan sumber sebagai pembuat atau pengirim informasi. Dalam komunikasi antar manusia, sumber bisa terdiri dari satu orang, tetapi bisa juga dalam bentuk kelompok, seperti partai, organisasi atau lembaga. Sumber sering disebut pengirim, komunikator, atau dalam bahasa inggris disebut source, sender, atau encoder

2. Pesan

Pesan yang dimaksud dalam proses komunikasi adalah suatu yang disampaikan pengirim kepada penerima. Pesan dapat disampaikan dengan cara tatap muka atau melalui media komunikasi. Isi pesan bisa berupa Ilmu pengetahuan, hiburan, informasi, nasihat atau propaganda.

\section{Media}

Media yang dimaksud disini adalah alat yang digunakan untuk memindahkan pesan dari sumber kepada penerima. Terdapat beberapa pendapat melalui saluran atau media. Ada yang menilai bahwa media bisa bermacam-macam bentuknya, misalnya dalam komunikasi antarpribadi panca indra dinggap sebagai media komunikasi. Selain indra manusia,ada juga saluran komunikasi seperti telepon, surat, telegram yang digolongkan sebagai media komunikasi antarpribadi.

Selain komunikasi antarpribadi, juga terdapat tipe komunikasi yaitu komunikasi massa, dimana medianya merupakan alat yang dapat menghubungkan antara sumber dan penerima yang sifatnya terbuka dimana setiap orang dapat melihat, membaca dan mendengar. Media dalam komunikasi massa terdiri dari dua macam yaitu media cetak, seperti surat kabar, majalah, buku, brosur, stiker, buletin, spanduk, poster dan lain sebagainya. Dan media elektronik radio, film, televisi, video reckording dan lain-lain.

\section{Penerima}

Penerima adalah pihak yang menjadi sasaran pesan yang dikirim oleh sumber. Penerima bisa terdiri dari satu orang atau lebih, bisa juga dalam bentuk kelompok, partai dan negara. Penerima biasa disebut dengan berbagai macam istilah, seperti Khalayak, sasaran, komunikan atau dalam bahasa inggris disebut audience atau receiver. Dalam proses komunikasi, telah dipahami bahwa keberadaan penerima adalah akibat karena adanya 
sumber. Tidak ada penerima, jika tidak ada sumber. Atau dengan kata lain, penerima adalah element penting dalam komunikasi, karena dialah yang menjadi sasaran dari komunikasi. Jika suatu pesan tidak bisa diterima oleh penerima akan menimbulkan berbagai macam masalah yang seringkali menuntut perubahan apakah pada sumber, pesan atau saluran.

\section{Efek}

Pengaruh atau efek adalah perbedaan antara apa yang dipikirkan, dirasakan, dan dilakukan oleh penerima sebelum dan sesudah menerima pesan. Pengaruh ini bisa terjadi pada pengetahuan, sikap dan tingka laku seseorang De Flour (1982). Oleh karena itu pengaruh bisa juga diartikan perubahan atau penguatan keyakinan pada pengetahuan, sikap, dan tindakan seseorang sebagai akibat peneimaan pesan.

\section{Umpan Balik}

Ada yang beranggapan bahwa umpan balik sebenarnya adalah salah satu bentuk daripada pengaruh yang berasal dari penerima. Akan tetapi umpan balik bisa juga berasal dari unsur lain seperti pesan dan media. Meskipun pesan belum sampai pada penerima. misalnya sebuah konsep surat yang memerlukan perubahan sebelum dikirim, atau alat yang digunakan untuk menyampaikan pesan itu mengalami gangguan sebelum sampai ke tujuan.

\section{Lingkungan}

Lingkungan atau situasi adalah faktor-faktor tertentu yang dapat mempengaruhi jalannya komunikasi. Faktor ini dapat digolongkan ke dalam empat macam, yakni lingkungan fisik, lingkungan sosial budaya, lingkungan psikologi dan dimensi waktu. Lingkungan fisik menunjukan bahwa suatu proses komunikasi hanya bisa terjadi kalau tidak terdapat rintanga fisik, misalnya georgrafis. Komunikasi seringkali sulit dilakukan karena faktor jarak yang begitu jauh, dimana tidak tersedia fasilitas komunikasi seperti telepon, kantor pos dan lainnya. Lingkungan sosial menunjukan faktor sosial budaya, ekonomi dan politik yang bisa menjadi kendala terjadinya komunikasi, misalnya kesamaan bahasa, kepercayaan, adat istiadat dan status sosial. Dimensi psikologis, adalah pertimbangan kejiwaan yang digunakan dalam berkomunikasi. Misalnya menghindari kritik yang menyinggung perasaan orang lain, menyajikan meteri yang sesuai dengan usia khalayak. Sedangkan dimensi waktu menunjukan situasi yang tepat untuk melakukan kegiatan komunikasi.

\section{Harmonisasi Komunikasi}

Kata harmonisasi berasal dari bahasa Yunani, yaitu dari kata "harmonia" yang artinya terikat secara serasi dan sesuai. Goesnidhie (2006: 59) mengatakan, harmoni merupakan keselarasan, kecocokan, keserasian, keseimbangan yang menyenangkan. Sedangkan Soetoprawiro (Goesnidhie, 2006) mengemukakan mengenai harmoni yang menjadi faktor paling penting di dalam kehidupan masyarakat, dengan mengatakan; Segala sesuatu yang baik dapat diterjemahkan ke dalam istilah harmoni. segala sesuatu yang senantiasa serasi, selaras, seimbang. Yang adil dan makmur adalah harmonis.

Jadi, dari defenisi diatas, dapat disimpulkan bahwa harmonisasi dapat diartikan sebagai suatu keadaan dimana tercapai keselarasan dan kedamaian tanpa ada perselisihan dan ketidaksepahaman. Ketika berkomunikasi 
keharmonisan itu sangatlah diperlukan guna mendukung terbentuknya komunikasi yang efektif sehingga komunikasi yang dilakukan bisa berjalan lancar dan dapat dipahami oleh masing-masing pihak. Kegagaln dalam berkomunikasi sering menimbulkan kesalahpahaman, kerugian dan bahkan dapat menyebabkan malapetaka. Resiko tersebut dapat terjadi pada segala tingkatan mulai dari tingkat individu, lembaga, komunitas dan bahkan negara. Keharmonisan sosial adalah suatu keadaan yang menunjukan adanya kondisi yang nyaman, teratur dan saling solid meskipun dihadapkan dengan berbagai perbedaan. Suranto (2011: 68)

Dalam membangun komunikasi yang harmonis di butuhkan adanya hal seperti berikut:

\section{Kebersamaan.}

Kebersamaan berasal dari kata 'sama, bersama'. Sama artinya seragam, sedangkan bersama artinya tidak sendiri. Jadi kebersamaan yang dimaksud disini adalah melaksanakan suatu kegiatan atau aktivitas secara bersama. Ciri kebersamaan yang baik adalah; 1) adanya tenggang rasa, 2) ada kekompakan, 3) ada kepentingan bersama, 4) saling mendorong dalam berbagai hal.

2. Saling memiliki.

Rasa saling memiliki sangat penting dalam suatu hubungan kerja, karena akan mendorong untuk saling menjaga dan melindungi.

\section{Keterbukaan.}

Liliweri, (2001: 173) mengemukakan secara ringkas, keterbukaan ialah:

a. Sikap seorang komunikator yang membuka semua informasi pribadinya kepada komunikan dan menerima semua informasi yang relevan tentang dan dari komunikan dalam rangka interaksi antarpribadi,

b. Kemauan seseorang sebagai komunikator untuk bereaksi secara jujur terhadap pesan yang datang dari komunikan, dan

c. Memikirkan dan merasakan bahwa apa yang dinyatakan seorang komunikator merupakan tanggung jawabnya terhadap komunikan dalam suatu situasi tertentu

4. Saling mengingatkan.

Dalam membangun suatu kerjasama yang baik dalam sebuah kelompok, tentunya antar individu di pandang penting untuk saling mengingatkan apabila ada individu yang lain keliru dalam melaksanakan tugasnya, hal ini kemudian mendorong tercapainya tujuan bersama.

5. Saling percaya.

Rasa saling percaya yang terdapat diantara orang-orang yang bekerja di suatu lingkungan kerja tertentu adalah salah satu unsur iklim kerja yang penting, karena kondisi psikososial ini menjadi syarat awal bagi berkembangnya sikap, motif, dan niat orang untuk menjalin kerja sama yang efektif.

Komunikasi yang harmonis akan menciptakan integritas yang baik. Melalui hubungan yang di dorong oleh rasa pengertian, keterbukaan, dan rasa memiliki serta kebersamaan. Komunikasi sangat penting dalam sebuah kelompok, pentingnya komunikasi dalam sebuah kelompok adalah dimana dalam melakukan pekerjaan diantara individu memerlukan komunikasi yang efektif. Dengan komunikasi yang efektif akan menciptakan hubungan kerja yang harmonis. Chen (2012: 67)

Dalam membangun kerjasama kelompok diperlukan keterbukaan atau transparansi, dan 
untuk menciptakan keterbukaan diperlukan kemauan dan kemampun setiap anggota kelompok untuk berkomunikasi. Berkomunikasi tidak hanya sekedar berbicara, tetapi bagaimana seseorang atau komunikator mampu mengeluarkan pendapat atau jalan pikirannya kepada orang lain, sehingga orang lain mau dan mampu menerima pendapatnya.

Kesamaan dalam berkomunikasi dapat diibaratkan dengan dua buah lingkaran yang bertindihan satu sama lain. Daerah yang bertindihan itu disebut kerangka pengalaman (field of experience), yang menunjukan adanya persamaan antara A dan B dalam hal tertentu, misalnya bahasa atau simbol.

Cangara, (2014: 23) mengemukakan model prinsip komunikasi, yang dapat di gambarkan sebagai berikut;

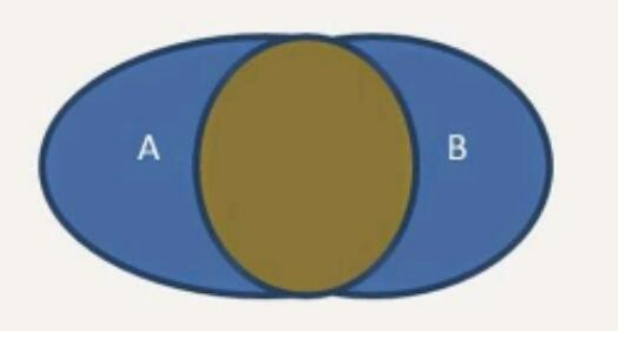

Gambar 2.2 Model prinsip komunikasi

Dari gambar di atas, dapat ditarik tiga prinsip dasar komunikasi, yakni:

1. Komunikasi hanya bisa terjadi bila, terdapat pertukaran pengalaman yang sama antara pihak-pihak yang terlibat dalam proses komunikasi (sharing similar experiences).

2. Jika daerah tumpang tindih (the field ofexperience) menyebar menutupi lingkaran A atau $B$, menuju terbentuknya satu lingkaran yang sama, makin besar kemungkinan tercipta suatu proses komunikasi yang efektif.
3. Tetapi kalau daerah tumpang tindih ini makin mengecil dan menjauhi sentuhan kedua lingkaran, atau cenderung mengisolasi lingkaran masing-masing, komunikasi yang terjadi sangat terbatas. Bahkan besar kemungkinan gagal dalam menciptakan suatu proses komunikasiyang eefektif.

4. Kedua lingkaran ini tidak akan bisa saling menutupi secara penuh (100\%) karena dalam konteks komunikasi antarmanusia tidak pernah ada manusia di atas dunia ini yang memiliki perilaku, karakter dan sifat-sifat yang persis sama.

\section{Jaring Bobo (Pukat Cincin)}

Jaring bobo adalah jenis jaring yang umumnya berbentuk empat persegi panjang, dilengkapi dengan tali yang dilewatkan melalui cincin yang di ikat pada bagian bawah jaring, sehingga dengan menarik tali bagian bawah jaring dapat dikerutkan, atau dengan kata lain memperkecil ruang gerak ikan, sehingga ikan-ikan dapat dengan mudah untuk di tangkap.

Menurut Ayodhyoa (1981) dalam Johannes (2014: 4) mengatakan, Pukat cincin adalah alat tangkap yang digunakan untuk menangkap ikan pelagis yang membentuk gerombolan. Ikan yang menjadi tujuan penangkapan dari pukat cincin adalah ikan-ikan pelagis Shoaling species yang berarti ikan-ikan tersebut haruslah membentuk gerombolan, berada dekat dengan permukaan air laut.

a. Komponen- komponen jaring bobo

Kapal

Pengoperasian alat tangkap jaring bobo membutuhkan unit penangkapan yaitu berupa kapal. Kapal ini berfungsi ketika pengoperasian 
yaitu untuk melingkari jaring pada gerombolan ikan. Kapal jaring bobo yang digunakan di kabupaten seram bagian barat terbuat dari kayu sebagai bahan dasar, dengan ukuran panjang antara 15-17.5 m, lebar 3.5-4 m, dan tinggi 2-2,5 m. Ratarata setiap kapal di lengkapi dengan 2 buah mesin penggerak yaitu mesin yamaha berkekuatan $40 \mathrm{PK}$. Bahan bakar yang digunakan ialah minyak tanah, bensin dan oli

\section{Jaring}

Alat tangkap yang digunakan nelayan ditujukan untuk menangkap ikan -ikan pelagis kecil yang berada di permukaan dan lapisan tengah perairan. Jaring bobo terdiri dari 3 bagian utama yaitu, kantong, badan dan sayap yang terbuat dari bahan multifilament. Kantong terletak dibagian tengah dengan ukuran mata jaring bervariasi antara 3/4", 1" dan 11/4". Badan terletak di bagian kiri dan kanan kantong dengan ukuran mata jaring 1", 1 1/4" dan $1 \frac{1}{2}$ ". Sayap terletak dibagian terluar kiri dan kanan dengan mata jarring $1 \frac{1 / 2}{2}$ dan 13/4". Pelampung yang digunakan juga bervariasi yakni, jenis pelampung Y-15, Y-12 dan MATRIX-18, dipasang pada tali pelampung dengan jarak tertentu. Pemberat terbuat dari bahan timah dan dipasang pada tali pemberat dengan jarak tertentu, selain itu cincin sebagai tempat lewatnya tali kulor juga terbuat dari bahan timah dan bersama-sama dengan pemberat berfungsi memberatkan gaya tenggelam pada jaring. Tali temali digunakan pada bagian tali pelampung, tali pemberat, tali ris atas dan bawah, serta tali kulor yang semua material pembentuknya ialah polyethylene (PE) dengan diameter bervariasi antara $10-16 \mathrm{~mm}$.

\section{Nelayan}

Nelayan adalah orang yang hidup dari mata pencaharian hasil laut. Rata-rata nelayan biasanya bermukim di di daerah pinggir pantai atau pesisir. Dilihat dari segi kepemilikan alat tangkap, nelayan dapat di bedakan menjadi tiga kelompok, yaitu (1) Nelayan juragan, yaitu nelayan yang memiliki alat tangkap yang di operasikan oleh orang lain. (2) Nelayan buruh, nelayan yang bekerja pada alat tangkap milik orang lain. (3) Nelayan perorangan, nelayan yang memiliki peralatan sendiri (Mulyadi 2005).

\section{b. Pengoperasian alat tangkap}

Tahapan operasi penangkapan dengan alat pukat cincin sama seperti proses penangkapan dengan alat lainnya yaitu persiapan, setting, hauling dan memindahkan hasil tangkapan. Urutan operasi dapat digambarkan sebagai berikut :

Pertama-tama haruslah diketemukan gerombolan ikan terlebih dahulu. Ini dapat dilakukan berdasarkan pengalaman-pengalaman, seperti adanya perubahan warna permukaan air laut karena gerombolan ikan berenang dekat dengan permukaan air, ikan-ikan yang melompat di permukaan terlihat riak-riak kecil karena gerombolan ikan berenang dekat permukaan. Buihbuih di permukaan laut akibat udara-udara yang dikeluarkan ikan, burung-burung yang menukik dan menyambar-nyambar permukaan laut dan sebagainya. Hal-hal tersebut diatas biasanya terjadi pada dini hari sebelum matahari keluar atau senja hari setelah matahari terbenam disaat-saat mana gerombolan ikan-ikan teraktif untuk naik ke permukaan laut. Tetapi dewasa ini dengan adanya berbagai alat bantu seperti fish finder waktu operasi pun tidak lagi terbatas pada dini hari atau senja hari, 
siang hari pun jika gerombolan ikan diketemukan segera jaring dipasang.

Pada waktu melingkari gerombolan ikan kapal dijalankan cepat dengan tujuan supaya gerombolan ikan segera terkepung. Setelah selesai mulailah purse seine ditarik yang dengan demikian bagian bawah jaring akan tertutup. Melingkari gerombolan ikan dengan jaring adalah dengan tujuan supaya ikan-ikan jangan dapat melarikan diri dalam arah horisontal. Sedang dengan menarik purse line adalah untuk mencegah ikan-ikan supaya ikan-ikan jangan dapat melarikan diri ke bawah. Antara dua tepi jaring sering tidak dapat tertutup rapat, sehingga memungkinkan menjadi tempat ikan untuk melarikan diri. Untuk mencegah hal ini, dipakailah galah, memukul-mukul permukaan air dan lain sebagainya. Setelah purse line selesai ditarik, barulah float line serta tubuh jaring (wing) dan ikan-ikan yang terkumpul dipindahkan ke atas kapal. Lama pengoperasian alat ini tidak lebih dari 30 menit hal ini dilakukan karena ikan yang bergerombol harus segera dilingkari jaring lalu ditangkap. Jika terlalu lama maka peluang keberhasilan mendapatkan ikan yang banyak sangat kecil.

\section{c. Hasil Tangkapan Ikan}

Hasil penangkapan ikan yang menjadi tujuan utama penangkapan jaring bobo adalah jenis ikan pelagis kecil “Pelagic Shoaling Species” yang berarti ikan-ikan tersebut haruslah membentuk shoal (gerombolan), berada dekat dengan permukaan air.

Hasil tangkapan yang diperoleh dikategorikan ke dalam hasil tangkapan utama dan hasil tangkapan sampingan. Hasil tangkapan utama merupakan hasil tangkapan yang merupakan tujuan utama nelayan, sedangkan hasil tangkapan sampingan merupakan tangkapan yang tidak sengaja tertangkap sewaktu alat tangkap dioperasikan.

Hal yang sama juga dikatakan Manalu (2003) ditinjau dari pemanfaatannya hasil tangkapan dibagi kedalam dua jenis yaitu:

Hasil tangkapan utama

Hasil tangkapan utama adalah komponen dari stok ikan yang utama dicari dari operasi penangkapan ikan. Hasil tangkapan utama merupakan sasaran utama dari alat penangkapan ikan yang digunakan.

\section{Hasil Tangkapan Sampingan}

Hasil Tangkapan Sampingan adalah ikan non target yang tertangkap dalam operasi penangkapan ikan. Tertangkapnya spesies ikan non target ini dapat disebabkan karena adanya tumpang tindih habitat antara ikan target dan non terget.

Hasil tangkapan sampingan atau yang disingkat HTS merupakan bagian dari hasil tangkapan total yang tertangkap secara bersamaan dengan spesies target yang diupayakan. Menurut Hall Kategori hasil tangkapan sampingan dibedakan menjadi dua yaitu:

Spesies yang kebetulan tertangkap, yaitu hasil tangkapan yang tertahan dan bukan merupakan spesies target dari operasi penangkapan ikan. Spesies yang kebetulan tertangkap ini ada yang dimanfaatkan oleh nelayan dan ada yang dibuang tergantung nilai ekonominya.

Spesies yang dikembalikan ke laut yaitu bagian dari hasil tangkapan sampingan yang dikembaikan ke laut karena pertimbangan ekonomi 
bernilai rendah atau karena spesies yang dilindungi oleh hukum

\section{d. Pola Bagi Hasil Tangkapan}

Pola bagi hasil adalah alternatif yang dikembangkan rata-rata masyarakat nelayan untuk mengurangi resiko. Menggunakan pola bagi hasil serta tidak memberikan upah secara riil, pada kenyataannya lebih dapat meningkatkan motivasi diantara karyawan dalam bekerja dilaut Acheson, (1981). Pola bagi hasil juga dapat mengurangi resiko bagi pemilik kapal, serta menjaminnya tidak memberi upah yang tidak sepadan bila mana hasil tangkapannya sedang buruk. Hal ini terjadi karena penghasilan nelayan yang tidak dapat ditentukan kepastiannya. tergantung dari jumlah ikan yang ditangkap, dan hasil penjualan yang dilakukannya.

Susilo (1987) dalam Mulyadi (2005: 77) mengatakan bahwa distribusi pendapatan dari pola bagi hasil sangatlah timpang diterima antara pemilik dan awak kapal. Secara umum hasil bagi bersih yang diterima oleh awak kapal dan pemilik adalah separo-separo. Akan tetapi bagian yang diterima awak kapal harus dibagi lagi dengan jumlah awak yang terlibat dalam aktifitas kegiatan di kapal. Semakin banyak jumah awak kapal, semakin kecil bagian yang diperoleh setiap awaknya. Dengan demikian, pemilik kapal ratarata menerima sekitar $65 \%$ dari keseluruhan hasil tangkapan. Sebaliknya rata-rata awak kapal akan mendapatkan hasil jauh lebih rendah dibandingkan dengan yang diperoleh pemilik. Bagian untuk awak kapal tersebut dibagi berdasarkan jumlah awak kapal yang terlibat. Semakin banyak jumlah awak, semakin kecil yang diperoleh awak kapal.
Untuk mendapatkan hasil tangkapan yang optimal, diperlukan suatu kerjasama yang erat dan kekompakan diantara sesama karyawan. Untuk itu lebih diharapkan keakraban atau kekerabatan diantara para karyawan.

\section{METODE PENELITIAN}

\section{Jenis Penelitian}

Jenis penelitian yang digunakan adalah penelitian deskriptif kualitatif. Rosady (2010:214), mengatakan qualitative research (Riset Kualitatif) merupakan jenis penelitian yang mendeskripsikan peristiwa di lapangan melalui wawancara untuk mendapatkan data, yang sesuai dengan tujuan penelitian. Pendekatan ini berbeda dengan penelitian kuatitatif yang menggunakan anggkaangka.

\section{Informan}

Informan dalam penelitian ini adalah nelayan di Kabupaten Seram Bagian Barat (SBB), yakni nelayan pemilik (juragan) dan nelayan buruh (masnait). Jumlah seluruh informan ada 22 orang, yang terdiri atas 6 Informan Pemilik (juragan) dan 16 informan buruh (masnait).

\section{Waktu dan Lokasi Penelitian}

Penelitian ini dilakukan sejak bulan Mei sampai Juni 2017, dengan lpkasi penelitian di Kabupaten Seram Bagian Barat (SBB).

\section{Metode pengumpulan data}

Pengumpulan data dilakukan dengan Observasi, dokumentasi dan wawancara berdasarkan pedoman wawancara terhadap informan di lapangan, guna mendapatkan data sesuai tujuan peneltian.

\section{Analisis data}


Analisis data dilakukan dengan menggunakan deskriptif kualitatif, dengan menjelaskan fenomena-fenomena yang terjadi di lapangan. Analisi data di lakukan dengan menggunakan moedel analisis Miles dan Huberman, dalam Sugiyono (2013: 335) mengemukakan model proses analisis data yang berlangsung secara interaktif. Data-data tersebut kemudian di kaji dan di klasifikasikan berdasarkan jenisnya. Setelah dilakukan klasifikasi, data kemudian dianalisis untuk mendapatkan kesimpulan.

\section{HASIL DAN PEMBAHASAN}

Harmonisasi Komunikasi antar nelayan di Kab. Seram Bagian Barat (SBB)

Imron (2003:24). Nelayan adalah masyarakat yang hidup di pesisir pantang, yang secara langsung kehidupan mereka sangat bergantung pada hasil laut. Nelayan merupakan sebuah kelompok, yang dalam melakukan upaya penangkapan ikan, sangat membutuhkan adanya kerjasama yang baik di antara sesama, hal penting lainnya adalah keharmonisan di antara mereka sangat di butuhkan, karena keharmonisan antar sesama dalam kelompok dapat menunjang tercapainya tujuan dari usaha tersebut. Nelayan di kabupaten Seram Bagian Barat, biasanya melakukan aktivitas melaut hamper setiap setiap, kecuali kondisi alam yang kurang baik, seperti angin kencang dan gelombang tinggi. Aktivitas melaut dilakukan pada malam hari sekitar pukul 3 malam sampai jam 8 pagi mereka kembali. Sebelum turun melaut, para nelayan sudah mempersiapkan peralatan tangkap, termasuk mempersiapkan bahan bakar minyak yang di gunakan pada mesin temple pada sore hari..
Nelayan dalam satu unit kapal terdiri dari 16 sampai 22 orang tergantung besar kecilnya ukuran jaring bobo yang digunakan. Berdasarkan pada hasil yang di peroleh penulis dalam melakukan penelitian terkait, harmonisasi komunikasi di kalangan nelayan jaring bobo di kabupaten Seram Bagian Barat, ditemukan bahwa, antar nelayan sering terjadi konflik yang menyebabkan komunikasi antar mereka tidak harmonis. Konflik merupakan suatu gejala sosial yang sering terjadi di masyarakat, yang kapan dan dimana saja bisa terjadi. Pelaku utama dalam konflik sendiri adalah masyarakat

Hal- hal yang mendorong timbulnya konflik dan integrasi adalah adanya persamaan dan perbedaan kepentingan sosial. Di dalam setiap kehidupan sosial tidak ada satu pun manusia yang memiliki kesamaan yang persis, baik dari unsur etnis, kepentingan, kemauan, kehendak, tujuan dan sebagainya. Konflik yang terjadi di masyarakat ada yang dapat di selesaikan, namun ada juga yang tidak hingga berdampak pada aksi kekerasan.

Taroda, dalam bukunya "Teori dan Manajemen Konflik" (2001:11) mengatakan bahwa, konflik adalah segala bentuk interaksi yang bersifat oposisi atau suatu interaksi yang bersifat antagonis (berlawanan, bertentangan, atau bersebrangan). Konflik terjadi karena perbedaan, kesenjangan, diantara individu dalam kelompok. Konflik yang terjadi di antara nelayan di kabupaten Seram Bagian Barat yang mengakibatkan disharmonisasi antar mereka terjadi karena, tidak adanya kejujuran antar mereka, baik dari juragan ke masnait, maupun dari masnait ke juragan. Samani dan Haryanto (2012:51), mengemukakan 
jujur adalah menyatakan apa adanya terbuka konsisten dengan apa yang di katakan dan dilakukan (berintegritas), dapat di percaya dan tidak curang. Menurut Naim (2012:132) jujur merupakan nilai penting yang harus di miliki setiap orang. Ketidakjujuran yang di lakukan juragan ke masnait berupa, bagi hasil (gaji/upah) yang tidak sesuai dengan hasil tangkapan, pembagian ikan makan yang tidak merata diantara masnait, serta tidak konsisten seorang juragan dalam hal pembagian hasil. Hal yang sama juga di lakukan oleh masnait yang di beri kepercayaan oleh pemilik untuk mengelola usahanya, terkadang masnait yang di percaya juga tidak jujur dalam melaporkan hasil tangkapan yang mereka miliki, selain itu, masnait juga kadang tidak ada rasa tanggung jawab dalam menjalankan tugas, mereka hanya berpikir untuk bekerja demi menghidupkan keluarga mereka, tanpa ada rasa tanggung jawab bersama dalam menjaga dan merawat usaha (jaring) milik orang. Menurut Fadilah dan Lilif (2013:27) tanggung jawab yaitu sikap dan perilaku seorang untuk melaksanakan tugas dan kewajibannya yang seharusnya dilakukan terhadap diri sendiri, masyarakat, lingkungan (alam, sosial, dan budaya).

\section{Upaya Membangun Komunikasi Yang} Harmonis Antar Nelayan

Proses dalam menjalankan sebuah usaha diperlukan adanya kesadaran akan kepentingan dan ancaman serta menyadari adanya keinginan untuk mencapai hasil yang di capai. Keinginan untuk mencapai tujuan tersebut, diperlukan kerjasama yang baik di antara individu dalam suatu kelompok usaha. Meskipun demikian, dalam menjalankan sebuah usaha tentu diperhadapkan dengan berbagai tantangan dan ancaman baik internal maupun eksternal.

Membangun hubungan komunikasi yang harmonis, sangat diperlukan dalam hidup dan kehidupan masyarakat. Dalam proses komunikasi yang harmonis diperlukan saling pengertian dan kerjasama timbal balik antara individu atau kelompok dalam menjalankan sebuah usaha. Karena itu, dalam menjalankan usaha jaring bobo, diperlukan upaya-upaya untuk membangun hubungan komunikasi yang harmonis. Hubungan komunikasi dalam penelitian ini terkait dengan keharmonisan antara masnait dan pemilik jaring bobo. Berdasarkan data yang penulis temukan, melalui wawancara dengan para informan, baik pemilik maupun masnait di temukan bahwa, upaya yang mereka gunakan dalam membangun komunikasi yang harmonis adalah adanya saling menghargai antara sesama baik pemilik dan masnait, rasa hormat dan saling menghargai merupakan unsur penting dalam menjaga hubungan sosial antar sesama. Saling menghargai antar sesama, dapat menciptakan kerjasama yang baik, hal ini juga dapat meningkatkan kinerja yang baik. Untuk itu saling menghargai merupakan suatu hal penting dalam membangun komunikasi yang harmonis, terutama nelayan yang dalam kelompoknya terdiri atas individu-individu yang punya latar belakang budaya dan agama yang berbeda. Upaya lain yang di lakukan adalah adanya kejujuran dan sifat terbuka, baik masnait maupun juragan. Kejujuran merupakan hal penting dalam sebuah kelompok usaha, dan perlu di tanamkan dalam diri individu, kejujuran berarti baik masnait maupun juragan sama-sama terbuka dalam 
melaporkan hasil tangkapan yang di peroleh. Bochner dan Kelly (1974) dalam Josep Devito (1997:259) menjelaskan bahwa, dari segi humanistik, efektifitas komunikasi memiliki 5 karakteristik utama, yaitu: Keterbukaan, Empati, Sikap Mendukung, Sikap Positif dan kesetaraan.

Keterbukaan mengacu pada pada tiga aspek dari komunikasi antarpribadi. Pertama, untuk menciptakan komunikasi yang efektif, tentunya komunikator harus terbuka terhadap komunikan. Terbuka yang dimaksudkan bukan termasuk informasi pribadi dari seorang komunikan. Tetapi termasuk juga dalam hubungan kerja, bagaimana seorang juragan atau masnait, sama-sama terbuka dalam melaporkan hasil dari usaha mereka. Kedua Kejujuran komunikator dalam melihat setiap stimulus yang di kemukakan komunikan. Ketiga menyangkut "kepemilikan" perasaan dan pikiran. Terbuka dalam pengertian ini adalah mengakui bahwa perasaan dan pikiran yang di sampaikan adalah memang benar-benar anda sampaikan dan anda yang bertanggung jawab atasnya. Liliweri, (2001: 173) mengemukakan secara ringkas, keterbukaan ialah: (1) Sikap seorang komunikator yang membuka semua informasi pribadinya kepada komunikan dan menerima semua informasi yang relevan tentang dan dari komunikan dalam rangka interaksi antarpribadi, (2) Kemauan seseorang sebagai komunikator untuk bereaksi secara jujur terhadap pesan yang datang dari komunikan, dan (3) Memikirkan dan merasakan bahwa apa yang dinyatakan seorang komunikator merupakan tanggung jawabnya terhadap komunikan dalam suatu situasi tertentu
Komunikasi sangat berperan penting dalam segala aspek kehidupan, termasuk dalam suatu masyarakat maupun kelompok tertentu. Dimana komunikasi berperan sebagai alat untuk menyampaikan maksud dan tujuan antar satu sama lain agar terjalin suatu kerjasama yang harmonis.

Susanto (1982 : 124), dalam bukunya Komunikasi Kontemporer mengatakan bahwa, suatu komunikasi yang harmonis, mencerminkan suatu situasi dimana komunikator dan komunikan mengerti satu sama lain, saling mempengaruhi dan bahwa hasil komunikasi akan memuaskan kedua belah pihak. Kepercayaan akan ditingkatkan melalui komunikasi yang harmonis dan integrasi suatu kelompok akan meningkat pula. Perubahan sikap dan tingkah laku seseorang ditimbulkan oleh suatu pesan yang dirasakan sebelum dan sesudah menerima pesan.Ini berarti pesan merupakan unsur penting dalam menciptakan hubungan yang harmonis.

Agar komunikasi dapat berjalan lancar, dan dapat di terima oleh semua pihak, tentunya di harapkan adanya komunikasi yang harmonisasi, agar terjalin komunikasi yang efektif diantara sesama

\section{SIMPULAN}

Dari temuan di lapangan dapat di simpulkan bahwa: (1). Komunikasi antar nelayan jaring bobo di Kabupaten Seram Bagian Barat sering terjadi konflik yang menyebabkan komunikasi antar mereka tidak harmonis. Konflik di antara nelayan di sebabkan karena, tidak adanya kejujuran/Keterbukaan antar nelayan, (2). Upaya yang di lakukakan nelayan dalam membangun komunikasi yang harmonis antar sesama antara 
lain, adanya saling menghargai antara sesama baik pemilik dan masnait, adanya kejujuran dan sifat terbuka, menjalin hubngan kerjasama yang baik demi menjalankan usaha jaring bobo.

Saran dalam penelitian ini antara lain: (1). Terutama kepada kelompok nelayan yang dalam kehidupannya sangat bergantung pada hasil laut, agar supaya tetap menjaga keharmonisan dalam kelompok, karena hal ini dapat tercipta kerjasama yang baik antar sesama, kerjasama yang baik antar individu dalam kelompok dapat membantu kelompok dalam mendapatkan hasil tangkapan yang lebih baik. (2). Baik Juragan maupun masnait, agar supaya menyadari tanggung jawab masingmasing yang telah di sepakati bersama. Juragan melaksanakan tugasnya untuk memenuhi hak-hak para masnait dengan baik, dan tugas masnait adalah sama-sama saling bersinergi dalam menjalankan usaha jaring bobo tersebut. (3). Perlu kesadaran dari semua pihak terutama jurgan dalam memenuhi hak-hak nelayan secara jujur, termasuk dalam proses bagi hasil.

\section{DAFTAR PUSTAKA}

Aw.Suranto. (2011). Komunikasi Interpersonal. Yogyakarta: Graha Ilmu.

Bugin. (2008). Sosiologi Komunikasi. Jakarta: Prenada Media Group.

Cangara, H. (2014). Pengantar Ilmu Komunikasi. Jakarta: Grafindo.

(2014). Perencanaan dan Strategi Komunikasi. Jakarta: Grafindo.

Chen. (2012). Menciptakan Keharmonisan Di Dunia Kerja. Jakarta: Bhuana Ilmu.

Dana, D. (2006). Resolusi Konflik. Jakarta: Buana Ilmu.

Devito, J. (1997). Komunikasi Antarpribadi. Jakarta: Profesional Books.
Effendy, O. U. (2013). Ilmu Komunikasi Teori dan Praktek. Bandung: Rosdakarya. Cet.25

(2008). Dinamika Komunikasi. Bandung: Remaja Rosdakarya

Gunawan, I. (2016). Metode Penelitian Kualitatif (Teori Dan Praktek). Jakarta: Bumi Aksara.

Imran. (2003). Kemiskinan Dalam Masyarakat Nelayan. Jakarta: PMB-LIPI.

Kriyantono. (2010). Teknik Praktis Riset Komunikasi. Jakarta: Kencana Prenada.

Lauer, R. (2001). Perspektif Tentang Perubahan Sosial. Jakarta: Rineka Cipta.

Liliweri, A. (2001). Gatra-Gatra Komunikasi Antarbudaya. Yogyakarta: Pustaka Pelajar.

Littlejohn \& Fross. K . A. (2008). Teori Komunikasi. Jakarta: Salemba Humanika.

Mulyadi. (2005). Ekonomi Kelautan. Jakarta: Raja Grafindo.

Mulyana, D. (2010). Ilmu Komunikasi : Suatu Pengantar. Bandung: Rosdakarya.

Bandung: Rosdakarya.

Moleong, L. (2007). Metodologi Penelitian Kualitatif. Bandung: Rosdakarya.

Naim, N. (2012). Character Buiolding : Optimalisasi Peran Pendidikan Dalam Pengembangan Ilmu dan Pembentukan Karakter Bangsa. Jogjakarta: ArRuz Media.

Narwoko.J. Dwi dan Suyanto, Bagong (2005). Sosiologi Teks Pengantar dan Tertapan. Jakarta: Kencana Prenada Media Group.

Nasrullah, R. (2012). Komunikasi Antarbudaya di Era Budaya Siber. Jakarta: Kencana.

Nasikun. (2003). Sistm Sosial Indonesia. Jakarta: Raja Grafindo Persada.

Rohim, S. (2009). Teori Komunikasi, Perspektif, Ragam, dan Aplikasinya. Jakarta: Rineka Cipta.

Ruslan, R. (2010). Metode Penelitian Public Relations dan Komunikasi. Jakarta: Grafindo Persada. 
Haryanto, M. S. (2012). Konsep dan Model pendidikan Karakter. Bandung: Remaja Rosdakarya.

Kolip, E. dkk (2011). Pengantar Sosiologi Pemahaman Fakta dan gejala Permasalahan Sosial: Teori Aplikasi dan Permasalahannya. Jakarta: Kencana Prenada Media Group.

Sugiyono. (2013). Metode Penelitian Kombinasi (Mixed Methods). Bandung: Alfabeta.

Tunner, W. d. (2008). Pengantar Teori Komunikasi : Analisis dan Aplikasi. Jakarta: Salemba Humanika.

Wiryanto. (2006). Pengantar Ilmu Komunikasi. Jakarta: Grasindo.

Masturganda. (2005). Jaring insang-Gillnet: Serial Penangkapan Ikan Berwawasan Lingkungan. Bogor: Institut Pertanian Bogor. 